\title{
Świadomość cielesności ducha i duchowości ciała w procesie wychowywania człowieka. Opis w kontekście bioenergetycznej analizy charakteru Aleksandra Lowena oraz porządku wartości Maxa Schelera
}

\begin{abstract}
Abstrakt
Reprezentując holistyczną antropologię, Autorka opisuje w niniejszym tekście mechanizm zależności zachodzący pomiędzy wychowawczą intencją uzdolnienia człowieka do przeżyć duchowych oraz „przekazem” wartości wyższego rzędu a psychofizycznymi reakcjami ciała, które są na nie bezpośrednią odpowiedzią. Czyni to w oparciu o fenomenologiczną koncepcję wartości Maxa Schelera oraz teorię bioenergetycznej analizy charakteru Aleksandra Lowena. Pojęciem wiążącym ciało i umysł są emocje i uczucia, zaś pełna integracja i dojrzałość osobowości człowieka przejawia się (według Lowena) w gracji - rozumianej przez niego jako duchowe przeżywanie przyjemności.
\end{abstract}

Słowa kluczowe: wychowanie, wartości, ciało, gracja, duchowość, bioenergia.

\section{Awareness of Spirit Corporeality and Body Spirituality within the Process of Educating Humans. A Description within the Context of Alexander Lowen's Bioenergetics Analysis of Character and Max Scheler's Order of Values}

\begin{abstract}
In the following text, the author, representing holistic anthropology, describes the mechanism of dependencies occurring between the educational intention of enabling the human for spiritual experiences, and the "traduction" of higher degree values, and
\end{abstract}

* Uniwersytet Jagielloński.

Artykuł otrzymano: 4.11.2020; akceptacja: 22.12.2020. 
the psychophysical reactions of the body, being the direct response to the former. The description is based on the phenomenological theory of Max Scheler and the bioenergetics character analysis theory of Alexander Lowen. The concept that binds the body and the mind consists of emotions and feelings, while the complete integrity and maturity of human personality is displayed (according to Lowen) in grace - which he perceived as a spiritual experience of pleasure.

Keywords: education, values, body, grace, spirituality, bioenergy.

\section{Określenie perspektywy studiów - wprowadzenie}

Tak zapisany tytuł sugeruje odbiorcę tekstu, a mianowicie osoby, które tymże procesem wychowania się zajmują. Mogą to więc być wszystkie osoby zainteresowane, lecz przede wszystkim chodzi mi o grupę profesjonalistów, do której zadań należy również poszerzanie świadomości osób bezpośrednio lub pośrednio włączających się i swoim postępowaniem stymulujących proces rozwoju dziecka również w jego obszarze duchowym. Celem niniejszej wypowiedzi jest zwrócenie uwagi na zależności zachodzące pomiędzy przeżyciami z poziomu wartości duchowych i ich cielesnymi przejawami, które mogą zachodzić w wyniku międzyludzkiej relacji w okresie wychowywania człowieka. Efekty aksjologicznych jakości tych relacji, zachodzących głównie w okresie wczesnego dzieciństwa, przyjmują rolę nieświadomych skryptów, które w latach późniejszych wyznaczają aksjologiczne kierunki życia człowieka, stymulując jego poglądami, przekonaniami i zachowaniami (słowami, postawami czy „mową ciała”). Biorąc pod uwagę perspektywę pedagogiczną, która polega na tym, że pedagog, wchodząc w relację wychowawczą z żywym człowiekiem w konkretnej sytuacji, ma do dyspozycji z jednej strony efekty studiów filozoficznych, a z drugiej efekty badań empirycznych (w tym klinicznych) i dokonywanych na ich bazie spostrzeżeń oraz uogólnień, wykorzystałam w niniejszym tekście poglądy i opisy przypadków klinicznych przeprowadzone przez Aleksandra Lowena oraz zinterpretowany przez Józefa Tischnera porządek wartości Maxa Schelera.

Nie jest więc przedmiotem zainteresowania sama konfrontacja teorii wartości Maxa Schelera z koncepcją bioenergetycznej analizy charakteru Aleksandra Lowena, lecz pokazanie dwóch perspektyw opisu ludzkich doświadczeń, które uwzględniam w namyśle nad tym, jak przebiega pomiędzy ludźmi przekaz tego, co ważne i dla ich życia uznane za wartościowe. Innymi słowy pytanie brzmi: co i jak w człowieku bierze udział w wychowawczym procesie przekazu wartości duchowych? Natomiast teza ukierunkowująca odpowiedź jest taka, że biorą w nim udział przeżycie, umysł oraz ciało. I, że w ludzkim doświadczeniu związane są one ze sobą hermeneutyczną, spiralną zasadą „części i całości”. Wartości ${ }^{1}$ (czyli o różnej ważno-

\footnotetext{
1 Jestem zdania, że w procesie wychowania nie zachodzi przekaz wartości jako takich, lecz raczej ważność czy wartościowość określonych spraw/fenomenów oraz ich układy.
} 
ści/hierarchii/ludzkie fenomeny życia) są w tym ujęciu czymś, co nie tylko angażuje ludzki umysł i uczucia, lecz również ciało. Interesującej dla pedagoga wiedzy w tym zakresie dostarcza w moim przekonaniu również współczesna bioenergetyka, która wywodząc się z psychoanalitycznej koncepcji rozwoju osobowości dziecka (Grzegołowska-Klarkowska 2015), zwraca uwagę na rodzaj uczuciowo-fizycznych więzi łączących dziecko i opiekuna charakterystycznych dla teorii relacji z obiektem (Kaplan 2014) czy teorii przywiązania Bowlby'ego (Bowlby 2007).

To, co też według mnie łączy perspektywy studiów prowadzonych przez Schelera, a potem Tischnera ${ }^{2}$ oraz Lowena to świat przeżywany ${ }^{3}$. To żywe ludzkie doświadczenie badane przez Schelera i Tischnera na sposób filozoficzny, a przez Lowena empiryczny. To żywe, ludzkie doświadczanie wartości, w którym i biologia ciała bierze aktywny udział. Nie tylko w odniesieniu do wartości niższego rzędu, lecz również tych z rzędu wyższego, które zasadniczo jednak bardziej łączone są z poznaniem intelektualnym (Olbrycht 2000). Wydaje mi się szczególnie ważne, by w czuwającym nad rozwojem człowieka procesie wychowania wiedzieć, co dzieje się w sferze cielesnej, kiedy poruszana jest struna spraw i uczuć z poziomu wartości duchowych. Mieć świadomość tego, że: (1) na wartości duchowe reaguje również ciało, zwłaszcza w okresie dzieciństwa, i że te ślady wtedy zapisane są rozpoznawalne w późniejszym życiu dorosłym, (2) że te ślady przekazu pozytywnych i negatywnych wartości duchowych posiada w swoim ciele również on sam jako rodzic czy wychowawca oraz tego (3) jaką spełniają one funkcję w prowadzonej przez niego relacji pedagogicznej4.

Układ treści jest następujący: w pierwszej kolejności przedstawione zostaną informacje wprowadzające $\mathrm{w}$ historię oraz rozumienie użytych $\mathrm{w}$ tytule pojęć, a w drugiej kilka sytuacji egzemplifikujących jakość związku zachodzącego pomiędzy światem przekazywanych przez dorosłych wartości, rezonansem emocjonalnym i uczuciowym dziecka, reakcjami jego ciała a faktycznym poziomem wartości urzeczywistnionych.

\footnotetext{
2 Korzystam jednak przede wszystkim z interpretacji tischnerowskiej (Tischner 1984), ponieważ ujmuje ona zagadnienie sposobu istnienia oraz porządku wartości w sposób zwięzły i klarowny, umożliwiając tym samym osobom nieposiadającym głębszego przygotowania filozoficznego wgląd w istotę zagadnień aksjologicznych istotnych z pedagogicznego punktu widzenia - jeśli wychowanie rozumieć jako zasadniczo intencjonalną pomoc człowiekowi w procesie określania jego osobistej tożsamości aksjologicznej, zwłaszcza w okresie dzieciństwa i dorastania. Tischnerowskie, a też fenomenologiczne przybliżenie apriorycznego porządku wartości wskazanego przez Maxa Schelera (Scheler 1975: 161-168) oraz rozwinięcie tematu sensowności relacji zachodzących pomiędzy poszczególnymi szczeblami wartości służy w tym tekście jako narzędzie dopełniające perspektywę psychologiczną.

3 Termin też zapożyczam z fenomenologii i jej rozumienia doświadczenia (zob. Rolewski 1999).

${ }^{4}$ Negatywnym tego przykładem są choroby psychosomatyczne oraz autoagresywne (np. anoreksja lub bulimia).
} 


\section{Geneza koncepcji bioenergetycznej analizy charakteru Aleksandra Lowena}

Dr Aleksander Lowen to współczesny, amerykański psychiatra i psychoterapeuta (1910-2008), upowszechniający i rozwijający bioenergetyczną koncepcję analizy charakteru człowieka. Główne jej podstawy Lowen zapożyczył od swego nauczyciela i psychoterapeuty Wilhelma Reicha5 (1897-1957), który opracowywał je w dyskusji z freudowską koncepcją libido jako stłumionej siły seksualnego popędu, kierującej ludzkimi zachowaniami ze sfery nieświadomości (Reich zetknął się z Zygmuntem Freudem w 1919 r.). W konfrontacji z brakiem społecznego przyzwolenia na spontaniczne ujawnianie się tej siły człowiek znajdował się w sytuacjach osobowościowego i kulturowego konfliktu. Jedyną, akceptowalną formą jej ujawniania się (z jakiej człowiek mógł skorzystać) była ujęta w normy moralne kulturowa ekspresja. Reich rozwinął jednak własną koncepcję specyficznej, biologicznej siły życiowej, o kosmicznym pochodzeniu, którą nazwał orgon (Lowen 2012). Wiązał ją, zgodnie z założeniami psychoanalizy, z seksualnością, lecz to w jej uwolnieniu i swobodnym przepływie przez ludzkie ciało upatrywał szansy na równoważenie sił duchowych i cielesnych, które z kolei ujawniając się w doświadczeniu przyjemności, stanowiły o zdrowiu człowieka. Sam Reich, ze względu na sposób propagowania i realizowania swoich poglądów, nazwany został twórcą rewolucji seksualnej (w 1936 r. wydał książkę The Sexual Revolution) i był postacią mocno kontrowersyjną w środowisku psychiatrów, psychoterapeutów oraz ówczesnych polityków zarówno w Austrii, Niemczech, Norwegii, jak i Stanach Zjednoczonych (tam jego książki oficjalnie spalono w 1956 r.). Niemniej miał też znaczących zwolenników w osobach np. Bronisława Malinowskiego czy Aleksandra Sutherlanda Neilla, twórcy Szkoły Summerhill (Neill 1992: 321-3296). To, co jednak może zainteresować pedagogów, to właśnie zapoczątkowana przez Reicha analiza charakteru człowieka z perspektywy jego ciała. Opublikowana w 1933 r. książka Charakteranalyse: Technik und Grundlagen fuer studierende und praktizierende

\footnotetext{
5 Informacje nt. W. Reicha zaczerpnięte zostały ze strony: https://peoplepill.com/people/wilhelmreich/. Lowen odwołuje się też w dużym zakresie do jego koncepcji w książce Język ciała. Jak ciało pokazuje osobowość. Fizyczna dynamika struktury charakteru (2012), w której omawia teoretyczne założenia Analizy Bioenergetycznej, które uzasadniają charakterystyczne dla niej techniki terapeutyczne.

${ }^{6}$ W 1937 r. Neill miał odczyt, którego słuchaczem był również Reich. Spotkali się wieczorem, a Neill powiedział: „(...) jesteś człowiekiem, którego szukałem od lat, człowiekiem łączącym soma i psyche. Czy mogę u ciebie studiować?”. I tak Neill przez dwa kolejne lata w czasie urlopów jeździł do Oslo. Uczył się od Reicha jego teorii oraz przechodził terapię nazwaną przez Reicha wegetoterapią. Opisuje to następująco: „oznaczała ona leżenie nago na kozetce, podczas gdy on (Reich - przyp. aut.) przypuszczał atak na moje sztywne mięśnie. (...) To była intensywna terapia i często bolesna, ale po kilku tygodniach poczułem się bardziej emocjonalnie wyzwolony niż po terapii, jakiej poddawali mnie Lane, Maurice Nicoll czy Stekel" (Neill: 322-333). Zafascynowany techniką dotyczącej nerwic pracy terapeutycznej Reicha bardzo przestrzegał przed tym, by nie stosowali jej niedoświadczeni psycholodzy i psychiatrzy. Wyzwalała ona bowiem silne, głębokie i trudne emocje, związane z wczesnodziecięcymi przeżyciami.
} 
Analityker (wydanie poprawione i przetłumaczone na język angielski ukazało się w roku 1946 i 1949 pod tytułem Character Analysis) stała się dla psychoanalizy punktem zwrotnym w interpretacji genezy powstawania struktury charakteru. Reich odnalazł bowiem funkcjonalną zależność pomiędzy charakterem, emocjonalnymi blokami i tendencją ciała, której efekt nazywał zbroją (pancerzem) charakteru (ew. muskulatury ciała). Był zdania, że ów pancerz ciała jest obroną, która zawarła w sobie traumy dzieciństwa, głównie powiązane z kompleksem Edypa i będące rozwojowym źródłem nerwic. Twierdził, że impulsy popędowe, w których tkwi życiowa energia, zostały zatrzymane w pancerzu muskulatury ciała i że znacznie lepiej jest je wyrazić na zewnątrz aniżeli „przetrawiać” we własnym wnętrzu. „Rozpuszczanie” (dissolving) „zbroi ciała” miało pomóc w przywracaniu pamięci represji, które w dzieciństwie były przyczyną powstałych, a do dziś widocznych w ciele, blokad emocjonalnych (https://peoplepill.com/people/wilhelm-reich/).

Można powiedzieć, że stosowane przez Reicha metody były dość ekstremalne i dziś, przynajmniej według mojej wiedzy nt. praktyki terapii bioenergetycznej, niestosowane. Przyjęte natomiast zostały jego wnioskowania teoretyczne, stając się głównym założeniem bioenergetyki, którą rozwijali współpracujący na początku ze sobą dwaj uczniowie Reicha: John Pierrakos ${ }^{7}$ i Aleksander Lowen.

\section{Duchowość}

W odniesieniu do procesu wychowywania człowieka chcę wykorzystać rozumienie duchowości w kontekście zaproponowanej przez Maxa Schelera koncepcji hierarchicznego układu wartości ${ }^{8}$, omówionej przez Józefa Tischnera w eseju Etyka wartości i nadziei (Tischner 1981: 56-80). Na potrzeby niniejszego tekstu przypomnę, że wartości duchowe znajdują się na trzecim szczeblu, ponad wartościami hedonistycznymi i witalnymi, a przed wartościami świętymi ${ }^{9}$. Wartości hedonistyczne (to co przyjemne/nieprzyjemne, praktyczne/niepraktyczne) oraz witalne (zdrowe/niezdrowe) nazwane zostały wartościami szczebla niższego, zaś wartości duchowe i święte wartościami szczebla wyższego. Porządkiem wskazanej hierarchii rządzi obiektywnie istniejący sens (logicznie też i bezsens), który polega na tym, że na każdym szczeblu wartości rzędu wyższego stanowią o sensowności urzeczywistniania wartości rzędu niższego. Poszczególne szczeble wartości, jak i zachodzą-

\footnotetext{
7 Dr John C. Pierrakos (1921-2001) prowadzoną już przez siebie samodzielnie holistyczną terapię ciała, ducha i duszy nazwał Core Energetik (J. Pierrakos 1987). Po śmierci żony Evy, również psychiatry, która opracowała własną ścieżkę osobistego rozwoju nazwaną Pfadwork (E. Pierrakos 1997) i po latach wspólnej pracy założył w 1973 r. w Nowym Yorku Institute of Core Energetics.

8 Scheler wskazaną problematyką zajął się w książce Der Formalismus in der Ethik und die Materiale Wertetik, s. 122-126. Podaję za tłumaczem tekstu A. Węgrzeckim (Węgrzecki 1975: 161).

9 Samo pojęcie „duchowości” jest oczywiście pojęciem zakresowo szerszym, często opatrzonym dodatkowo przymiotnikiem go charakteryzującym, np. duchowość religijna (np. Encyklopedia Katolicka 1983: 311-334).
} 
ca pomiędzy nimi sensowa zależność istnieją obiektywnie i człowiek nie ma na ich istnienie wpływu ${ }^{10}$. Jednakże, jako istota relacyjna w swej dynamicznej konstrukcji bytu per-se (przez się) staje, jak opisuje to Tischner (a też i inni fenomenolodzy ${ }^{11}$ ) „wobec” owego obiektywnie istniejącego porządku i sensu wartości. Człowiek, rozumiany jako persona, realizuje swoją subiektywną i indywidualną egzystencję poprzez posiadanie współwystępujących ze sobą dwóch dyspozycji: (1) do fenomenologicznego wglądu w obiektywny porządek wartości w świecie przez siebie przeżywanym (Lebenswelt) oraz (2) dokonywania świadomego wyboru pomiędzy zachodzącymi w danej sytuacji aksjologicznymi zależnościami.

W przedstawionym porządku realizacja wartości niższego rzędu nabiera więc sensu wtedy, kiedy są one urzeczywistniane w konkretnej sytuacji, w kontekście wartości duchowych (zob. też Ablewicz 2003b: 177-200). Na przykład, wygodny fotel służy odprężeniu i regeneracji wyczerpanych sił witalnych, które są potrzebne do twórczej pracy. Zapach pachnących róż pobudza zmysły, sprawia przyjemność, ta z kolei sprawia, że chce się żyć. Powstaje pomysł, by za ich pośrednictwem zaznaczyć ważność związku i zadbać o międzyludzkie relacje.

Wartości obiektywne umieszczone na pierwszym poziomie wartości duchowych (kulturowych) to: prawda/fałsz, dobro/zło i piękno/brzydota. Są one wzajem do siebie nieredukowalne i niepodmienialne, tak więc na poziomie ludzkiej egzystencji konkurują ze sobą i rywalizują o „palmę pierwszeństwa” w jednostkowych, zrelatywizowanych różnymi okolicznościami wyborach. W przeżywanych przez człowieka dylematach rywalizuje więc ze sobą nieraz to, co zdaje się prawdziwe, z tym, co może być dobre, to, co zdaje się być dobre, z tym, co jawi się jako piękne, i to, co odbiera człowiek jako piękne z tym to przyjmuje za prawdziwe ${ }^{12}$. Wartość, która zostanie wybrana, nada sens pozostałym i podporządkuje je sobie. Wybory dokonywane w odniesieniu i w ramach przytoczonych transcendentaliów (prawdy, dobra i piękna) są w życiu człowieka niejednokrotnie bardzo dramatyczne, a zachowanie idealnej pomiędzy nimi harmonii nieosiągalne. Z każdym bowiem wyborem ma miejsce jakaś strata i jakaś korzyść. Stąd biorą się rozterki, różnice stanowisk, dramaty i tragedie, a przeżywane przez człowieka konflikty stają się intensywne emocjonalnie i głębokie intelektualnie.

Kontynuując omawianie schelerowskiej hierarchii wartości, trzeba zwrócić uwagę, że dwa poziomy wartości niższego rzędu (hedonistyczne i witalne) są dla człowieka kierunkowskazem w urzeczywistnianiu tego, co służy bądź wpływa

\footnotetext{
${ }^{10}$ Scheler i Tischner reprezentują stanowisko aksjologicznego obiektywizmu. Scheler wskazuje na aprioryczny charakter wiedzy na temat „powiązań o charakterze starszeństwa między modalnościami wartości" (Scheler 1975: 161).

11 Władysław Stróżewski (krakowski filozof i seminarzysta Romana Ingardena) tak to ujmuje: „Idea człowieczeństwa zakłada także, że człowiek jest bytem stojącym wobec wartości i na realizację tych wartości niejako „skazanym” - jeśli tylko naprawdę chce być człowiekiem” (Stróżewski 1992).

${ }^{12}$ Każdy wybór, bez względu na swoją aksjologiczną jakość, dookreśla tożsamość człowieka. Zachodzi to zarówno na każdym szczeblu wartości, jak i pomiędzy nimi. Dylematy są jednak tym silniejsze, im wyższy jest szczebel wartości.
} 
destrukcyjnie na jego indywidualną kondycję biopsychiczną. Tischner podkreśla, że doświadczenie drugiego człowieka w kontekście etycznym (również on sam dla siebie jako persona) pojawia się jednak dopiero na poziomie wartości duchowych (Tischner 1984: 74). To z tego poziomu wypływa troska o innego. Należy tu dopowiedzieć z perspektywy antropologii i ogólnej, i pedagogicznej, że najbardziej podstawowym i pierwotnym jej przejawem jest proces wychowania. Możliwe wtedy staje się bycie w relacji z drugim w taki sposób, że wybory dokonywane są nie tylko w związku z samym pojawieniem się innego (który może np. zagrażać lub łączyć się z nami we własnym przede wszystkim interesie), lecz ze względu na Niego samego i jakoś przez Wybierającego rozumiane Jego dobro. Transcendentalia przejawiają się w ludzkiej egzystencji poprzez jeszcze inne, pochodne od nich przeżycia. Na przykład: miłości, przyjaźni, oddania, słowności, uczciwości, życzliwości, szacunku, pracowitości, prawdomówności, wierności, zachwytu, czułości, poczucia odpowiedzialności (np. Hildebrandt 1984; Olbrycht 2000), własnej wartości i godności, wolności czy sprawiedliwości. A też poprzez ich rewersy będące pochodnymi zła, fałszu czy brzydoty. Na przykład: lekceważenie, ośmieszanie, upokarzanie, wykorzystywanie, oszukiwanie, okłamywanie, celowe zaniedbanie, niszczenie, zniewolenie, pozbawianie wiary w dotychczasowy sens życia bez poddania nowego, pogarda, zdrada czy przemoc ${ }^{13}$.

Biorąc pod uwagę porządek wartości Maxa Schelera, można powiedzieć, że zmiany rozwojowe człowieka przebiegają według owych czterech kontekstów aksjologicznych: wartości utylitarno-hedonistycznych, witalnych, duchowych (kulturowych) i transcendentnych. Lecz jednocześnie koniecznym jest podkreślenie, że pojedyncze doświadczenia egzystencjalne (zdarzenia, relacje) uruchamiają doświadczanie wartości z każdego poziomu (Żurakowski14 1998: 145-151), w odmiennym jednak zakresie (czy intensywności). Zachodząca pomiędzy nimi zależność jest typu hermeneutycznego ${ }^{15}$ i polega na spiralnym nakładaniu się i rozszerzaniu znaczeń zachodzących pomiędzy częściami i całością. Każde zdarzenie pozostaje w jednoczesnym kontekście każdego poziomu doświadczenia wartości. Pulsują one jednak w nim z różną mocą. Jeśli całością jest więc życie człowieka, to np. w ślad za naruszeniem sfery cielesnej zostaje naruszona sfera uczuciowa oraz rozumowa (np. niemieszcząca się w pojmowaniu logicznym). Na przykład dorosły uderza dziecko, a kiedy ono płacze, zabrania mu tego. Nieraz też i transcendentna.

\footnotetext{
${ }^{13}$ Nie odnoszę się tu zupełnie do wartości estetycznych oraz ich relacji wobec prawdy i piękna, ponieważ status tego, co ładne, a co brzydkie jest bardzo zrelatywizowany; wydaje się też, że zależny od wartości prawdy i dobra.

${ }^{14}$ Np. Bogusław Żurakowski (1939-2020) zajmujący się wychowaniem przez literaturę był zdania, że w procesie kształcenia powinien zachodzić proces inspirowania do przeżywania wartości (Żurakowski 1998: 147).

${ }^{15}$ Hermeneutyka jest nauką o procesie rozumienia, którego głównym założeniem jest, że część nie może być zrozumiana bez całości, a całość bez swoich poszczególnych części i że najmniejsza zmiana w części powoduje reorganizację pozostałych części i tym samym doprowadza do jakościowej zmiany całości (Ablewicz 2003a: 294-295).
} 
Na przykład, gdy traci wiarę w pozaludzkie siły chroniące sens jego egzystencji. A młodsze dzieci przypisują taką właśnie moc opiekunom w przekonaniu, że „Oni Wszystko Mogą”. W samym splocie więc pojedynczego zdarzenia (np. drwiącego tonu słów ${ }^{16}$ ) otwiera się $\mathrm{w}$ doświadczeniu człowieka cała paleta jego subiektywnych doznań, uczuć i myśli. W perspektywie niniejszej koncepcji punktem wyjścia są emocje i uczucia, w których wyrażaniu bierze czynny udział ciało oraz intelekt. Należy też w tym miejscu przypomnieć, że sam fenomen „wychowywania człowieka" umiejscowiony jest w relacjach międzyludzkich na poziomie wartości duchowych (kulturowych) - etycznych.

\section{Wychowywanie człowieka ${ }^{17}$}

Podkreślając procesualność tego zjawiska oraz niemożliwy do określenia koniec osobowościowych przemian człowieka, dla których doświadczenia dzieciństwa i młodości mają znaczenie kluczowych punktów odniesienia zarówno w sposobie przeżywania rzeczywistości, jak i nadawaniu jej znaczeń, akcentuję na potrzeby tego tekstu wychowywanie jako relację zachodzącą pomiędzy dzieckiem (dorastającym) i dorosłym, w rozwijaniu której celem jest charakter człowieka oparty na wartościach duchowych, zwłaszcza etycznych i poznawczych. W wychowaniu chodzi bowiem przede wszystkim o to, jacy ludzie są i będą w przyszłości dla samych siebie nawzajem.

Wartości nie można jednak przekazać wprost, ponieważ - przynajmniej w ujęciu fenomenologów - potrzebują określonych (niezbywalnych) warunków do tego, by mogły się urzeczywistnić: i w subiektywnej osobowości człowieka i w obiektywnym wobec niego świecie zewnętrznym. Wartości nie udaje się przekazać w sposób, jaki dotyczy przedmiotu lub informacji ${ }^{18}$, ponieważ ich immanentną częścią są emocje i uczucia przeżywane przez człowieka w związku z określoną sytuacją. One też stanowią niezbywalny warunek wartościowania zdarzeń, dokonywania wyborów oraz poczucia wewnętrznej osobowościowej integracji. A o taką, zintegrowaną osobowość chodzi w procesie wychowywania i ona też jest zasadniczym celem pracy wychowawczej w ujęciu humanistyczno-egzystencjalnym, w którym analiza bioenergetyczna Lowena jest jedną z teorii dotyczących sposobu funkcjonowania

\footnotetext{
${ }^{16}$ Brzmienia wyrazów są jak nuty zapisane na partyturze palety wartości. To samo słowo może mieć wiele brzmień zależnych od jawnych bądź nieświadomych, choć czasem też świadomie manipulacyjnych intencji człowieka wypowiadającego. Z tematem tym wiąże się już problematyka komunikacji interpersonalnej.

${ }^{17}$ Celowo używam sformułowania „wychowywanie człowieka”, a nie tylko „wychowanie”, żeby podkreślić procesualność tego fenomenu oraz wynikający z niej jego tryb niedokonany.

${ }^{18}$ Mam tu na myśli zjawisko „moralizowania”, które sprowadza się do co najmniej lekceważenia (o ile nie, negowania) aktualnego stanu rzeczy (tego, co jest i jakie jest) i kategorycznym akcentowaniem tego, co być powinno (aspekt projekcji, wyobrażenia rzeczywistości). Taka postawa bardzo utrudnia, a czasem wręcz uniemożliwia realną przemianę, której punktem wyjścia jest to, co jest, a nie to, czego nie ma.
} 
człowieka. Integracja osobowości ma się dokonywać przede wszystkim w trzech aspektach ludzkiego bytu: fizycznym, emocjonalno-uczuciowym oraz intelektualnym.

\section{Bioenergetyczna koncepcja funkcjonowania człowieka - główne terminy i zasady}

Gracja. Zacznę od tego pojęcia, ponieważ nazywa ono zjawisko będące dla Lowena przejawem osobowości zintegrowanej, a tym samym zachowującej elastyczną harmonijność pomiędzy emocjami i uczuciami, rozumem oraz fizycznością. Powołując się na Aldousa Huxleya Lowen przytacza trzy postacie gracji rozumianej jako (1) wdzięk poruszania się zwierząt, (2) wdzięk człowieka łączący się z jego urokiem osobistym oraz (3) wdzięk duchowy, który odnosi do stanu „łaski”. Ten ostatni wiąże się z „uczuciem zadowolenia wyższego rzędu” (Lowen 1991: 9), które $\mathrm{w}$ tych rozważaniach kojarzę $\mathrm{z}$ dwojakiego rodzaju wartościami rzędu wyższego (w porządku opracowanym przez Maxa Schelera) - duchowymi-kulturowymi i duchowymi-transcendentnymi. Huxley wnioskuje, że człowiekowi do jego człowieczeństwa nie wystarcza gracja zwierzęcego ruchu, lecz że potrzebuje ten wdzięk uzupełnić świadomymi wyborami pomiędzy dobrem i złem (tamże: 10). Lowenowi chodzi jednak o coś więcej. Stawia bowiem tezę, że do prawdziwie pełnego uroku i łaskawości zachowania niezbędny jest wdzięk pochodzący z ciała. Ów spontaniczny i naturalny wdzięk (np. ruchów małego dziecka) potrzebuje być zakotwiczony w cielesnej przyjemności, ponieważ inaczej staje się zachowaniem pełnym pozy i „fasadą wzniesioną, by wzbudzać podziw i mamić świat” (tamże).

Prawdziwa gracja ciała - jak pisze Lowen - nie jest czymś wyuczonym, lecz stanowi część naturalnego wyposażenia człowieka jako jednego z boskich stworzeń. Jednak, gdy zostanie utracona, można ją odzyskać jedynie przez przywrócenie ciału jego duchowości. Aby to uczynić, należy zrozumieć, dlaczego i w jaki sposób jego wdzięk został utracony (tamże: 11).

Z perspektywy pedagoga jest interesujące, kiedy człowiek traci swą przyrodzoną grację, w jakich okolicznościach może to się dziać i jak to zachodzi, a też, kiedy i jak buduje fasadę, którą chce, by podziwiano, a tak naprawdę staje się ona więzieniem jego woli i ochoty.

Informacja o utracie gracji jest zdobywana pośrednio, z klinicznych i zarazem fenomenologicznych zapisów przypadków osób poddających się psychoterapii. Bardzo często, zwłaszcza w przypadku nerwic, opisy te pochodzą od osób bardzo dobrze funkcjonujących społecznie, radzących sobie z zewnętrznymi trudnościami, zajmującymi odpowiedzialne i wysokie stanowiska (wizualnie prezentującymi się też bardzo dobrze). Niemniej w ich codziennym przeżywaniu zachodzi coś, co 
utrudnia im rodzinne, koleżeńskie czy zawodowe relacje, poczucie więzi i interpersonalnego bezpieczeństwa, wprowadza w nocne lęki i bezsenność, przejawia się uporczywymi i nieprzyjemnymi myślami, przedłużającymi się stanami wewnętrznego napięcia i niepokoju, powtarzanymi czynnościami, nieadekwatnym do sytuacji nasileniem irytacji czy odwrotnie, zamknięciem w sobie, unikaniem spotkań i jakiejkolwiek bliskości, albo też jej nadmierną potrzebą. Jeśli te utrudnienia stają się zbyt uporczywe, osoba dorosła dobrowolnie podejmuje proces samopoznania, w którym pomaga mu psychoterapeuta. W trakcie ich pracy odsłaniane są te sytuacje, a na dobrą sprawę relacje, w których rozwojowa potrzeba dziecka była zdeprywowana lub w niewystarczający sposób zaspokojona przez osoby dorosłe. Czasem oczywiście dzieje się tak na skutek obiektywnych okoliczności (np. choroby dziecka czy matki, wyjazdu czy śmierci), częściej jednak, jak się wydaje, ma miejsce ze względu na brak wiedzy, podstawowej empatii czy choćby zdrowego rozsądku opiekuna. Do najbardziej znaczących w rozwoju dziecka osób należą oczywiście najbliżsi opiekunowie (głównie matka), lecz też osoby pracujące w instytucjach pedagogicznych. Najogólniej więc, można podsumować, że człowiek traci swą przyrodzoną grację ciała w procesie wychowania za sprawą psychofizycznych i duchowych relacji z ważnymi dla niego osobami. Lecz może ją też oczywiście dzięki nim rozwijać i umacniać, tak by w życiu dorosłym stała się dla niego podstawą zrównoważonego funkcjonowania osobistego i zawodowego oraz poczucia zdrowia i dobrostanu.

W zrozumieniu okoliczności, w jakich gracja ciała została utracona oraz jej ewentualnym przywróceniu, pomaga analiza bioenergetyczna i psychoterapia. Oba te procesy możliwe są do przejścia dla już człowieka dorosłego, który retrospekcyjnie wraca do kluczowych i często traumatycznych dla rozwoju własnej osobowości doświadczeń. Istnieje szansa, że obecna samoświadomość i trud zmiany pozwolą (mimo że przeszłych doświadczeń nie da się anulować) na odzyskanie, a może wyzwolenie zablokowanej gracji w postaci harmonijnego przepływu energii życia pomiędzy tym, co cielesne i tym, co duchowe. Łącznikiem między tymi dwiema sferami są uczucia. Lowen trafnie w moim przekonaniu stwierdza, że „przy braku uczuć ruchy stają się mechaniczne, a myśli zmieniają się w abstrakcje” (tamże). Łączę tu jego poglądy z schelerowskimi, że to właśnie uczucia odgrywają istotną rolę podczas subiektywnego doświadczania i wartościowania przez człowieka rzeczywistości oraz poczucia sensu (Scheler 1997) - co zresztą nie popada w sprzeczność z przekonaniem o obiektywnym istnieniu wartości, ich porządku oraz sensowych zależnościach.

Bioenergia. Ruch życia odbywa się jeszcze dla człowieka w dość tajemniczy sposób, niemniej łączony jest chyba we wszystkich kulturach z transcendentną siłą, która dynamizuje materię. Nazywany jest różnie i odmiennie też bywa rozumiana jego współzależność z ciałem i osobowością człowieka ${ }^{19}$. Lowen bazuje na reichow-

\footnotetext{
${ }^{19} \mathrm{Na}$ przykład w kulturze hinduskiej jest ona nazwaną prana, chińskiej chi, japońskiej $k i$, europejskiej pneuma czy duch.
} 
skiej interpretacji procesu energetycznego (obecnie już chyba dość powszechnego i udowodnionego naukowo), w którym umysł i ciało stanowią dwie różne, wpływające na siebie wzajemnie funkcje. Samą naturę (zasadę działania) tego procesu rozumiał jako pulsacyjną i zależną od fizycznej stymulacji zewnętrznej - przyjemnej i bolesnej. W przypadku stymulacji przyjemnej wzrastał przepływ krwi (zwiększała się energetyczność ciała), podczas symulacji bolesnej „towarzyszyło pewne wycofanie płynów z ciała” (Lowen: 31-32). Wynik tego eksperymentu oraz późniejsze badania doprowadziły Reicha do wniosku, „że w procesie życia bierze udział specjalny rodzaj energii", który nazwał orgon, a Lowen później bioenergiq̨. Jej właściwością jest to, że istnieje na głębokich poziomach fenomenu ludzkiego życia i organizuje je zarówno w jego funkcjach somatycznych, jak i psychicznych; umysłowych i cielesnych ${ }^{20}$. Sprawność funkcjonowania człowieka we wszelkich aspektach jego działalności - czy to bardziej cielesnej, czy umysłowej zależy więc od płynności przepływu i pulsowania (ruch sięgania i cofania jak np. przy oddechu, jedzeniu czy tworzeniu) energii skoncentrowanej na świadomych i nieświadomych celach $^{21}$. Z punktu widzenia przytaczanej konstrukcji, a też rozwoju osobowości bioenergia znajduje swój wyraz najpierw w ruchach, następnie uczuciach, myślach i wreszcie w ego i jego tożsamości (tamże: ryc. 2.2: 33). Sam proces analizy bioenergetycznej Lowen opisuje następująco:

W analizie bioenergetycznej, aby zrozumieć osobowość, badany jest każdy z poziomów. Z racji ich wyjątkowego znaczenia, w centrum uwagi znajdują się procesy energetyczne znajdujące się u podstawy piramidy. Tematem ciągłej oceny jest zasób energii danej osoby i sposób w jaki ona ją wykorzystuje (tamże: 32 ).

Wspomniałam wyżej, że procesy energetyczne przebiegają pulsująco. W przypadku mięśni te napinają się bądź rozluźniają, kurczą bądź rozszerzają. Proces ten zachodzi oczywiście dzięki oddechowi i prawidłowemu dotlenieniu organizmu²2. Mięsień ładuje się energią $w$ chwili wchodzenia w stan rozluźnienia, a rozładowuje w chwili kurczenia. Ta równomierna pulsacja zapewnia wysokie naładowanie energetyczne i zdrowe funkcjonowanie organizmu pomiędzy wysiłkiem i regeneracją (tamże: 40).

\footnotetext{
${ }^{20}$ Ze względu na rozmiary tego tekstu teorię tę przedstawiam w uproszczony sposób.

${ }^{21}$ Przepływ energii jeszcze bardziej obrazowo przedstawia Zinker jako cykl polegający na: uświadamianiu-świadomości-mobilizacji-kontakcie/działaniu-wycofaniu z kontaktu/odpoczynku, co jest wykorzystane w psychoterapii i pedagogice Gestalt (Zinker 1991; Sills, Fish, Lapwoth 1999; Żłobicki 2009).

${ }^{22} \mathrm{~W}$ niniejszym tekście nie poświęcam uwagi umiejętności harmonijnego oddychania i wydychania powietrza. Dla procesu równomiernego przypływu energii oba są równie ważne, ponieważ żeby płuca napełnić świeżym powietrzem, najpierw - do końca - trzeba je w wydechu opróżnić. Z logicznego punktu widzenia wydaje się to oczywiste, lecz w codziennym funkcjonowaniu w chwilach napięcia, to wydech zostaje zatrzymany (np. podczas powstrzymywania mówienia, gestu), a to z kolei uniemożliwia człowiekowi zrobienie wdechu. Reakcje te zachodzą automatycznie i dopiero uświadomione pozwalają na zachowanie regularności tego cyklu.
} 
Jako podsumowanie podstaw teoretycznych bioenergetyki zacytuję poniższy fragment:

Emocje są bezpośrednim wyrazem ducha danej osoby. Siłę ducha jednostki da się zmierzyć intensywnością jej uczuć, wielkość jej ducha - głębokością uczuć, a swobodę ducha spokojem jej uczuć. Kiedy poruszamy się z uczuciem, ruch jest pełen gracji, ponieważ jest rezultatem przepływu energii w ciele. Uczucia stanowią zatem klucz do gracji i duchowości w ciele (tamże: 78).

\section{Wychowanie i bioenergetyka}

Z pedagogicznego punktu widzenia interesujące jest więc to, w jaki sposób i w jakich sytuacjach energia życia i osobowego rozwoju może być wspierana, zaburzana bądź blokowana. Sam proces wykorzystywania energii do życia jest procesem naturalnym, lecz w znacznym stopniu, a w przypadku człowieka, warunkowanym kulturowo w relacjach z obiektywnymi okolicznościami i innymi ludźmi. Interpersonalna relacja pomiędzy rodzicami (a zwłaszcza mamą) i dzieckiem powstaje już w okresie prenatalnym, a można powiedzieć, że jeszcze wcześniej poprzez tworzenie biopsychicznych uwarunkowań środowiska, $\mathrm{w}$ jakim dziecko zostanie poczęte (np. Kaplan 2014: 59-66; Grzegołowska-Klarkowska 2015: 9). Przeżycia i nastawienia duchowe rodziców (w tym ich porządek wartości) docierają do dziecka poprzez materię jego żywego organizmu. Jego ciało za każdym razem współreaguje na to, co spotyka je w sferze przeżyć duchowych. Tak przejawia się pierwsze i podstawowe w rozwoju charakteru człowieka ucieleśnianie duchowości.

Ciało jest kształtowane przez to, czego doświadcza. (...) Reagując na czuły dotyk, ciało rozszerza się pod wpływem przyjemnego pobudzenia. Pozbawione bliskiego kontaktu ciało dziecka skurczy się i stanie się zimne. Jego wrażliwość na pobudzenie ulega zmniejszeniu, a wewnętrzna pulsacja zostanie zredukowana (Lowen 1991: 41).

Dziecko takie, np. w wieku szkolnym (potem dorosły) - jeśli nie nastąpią w porę sytuacje korektywne - będzie unikać bliskiego kontaktu. Jeśli dotyk jest zaborczy, nadużywający ciała dziecka, to z poziomu wartości duchowych płynie komunikat „Jesteś czymś (bo już nie kimś), kogo używam do własnych celów. Twoje ciało, a wraz z nim Twoje uczucia i myśli mają dla mnie wartość użytkową". Jakkolwiek bezpośredni i dominujący komunikat dorosłego płynie z poziomu wartości niższego rzędu (wartości biologiczne skoncentrowane wyłączenie na dobru własnego ego), to poprzez ciało dziecko odbiera komunikat na poziomie wartości rzędu 
wyższego, właśnie duchowych i osobowych ${ }^{23}$. Nie mam tu na myśli tylko dotyku przekraczającego erotyczne i seksualne potrzeby dzieci i młodocianych, lecz też takie, np. przytulanie, w którym to opiekun przytula się do dziecka, szukając w nim oparcia i czułości. Kiedy człowiek nie chce czyjejś bliskości to kurczy się, by we wszelki możliwy sposób zwiększyć dystans i zachować swoje granice. Kurczy się fizycznie i kurczy się emocjonalnie. Jego ciało i psychika przestają harmonijnie pulsować. Rozwijający życie bioenergetyczny ruch zostaje zatrzymany, czasem na całe życie zablokowany w postaci trwałego urazu, widocznego w napięciu mięśniowym, np. w spłyceniu oddechu, uniesionych barkach, rozbudowanych łydkach i słabych udach (lub odwrotnie). Postulatywnie dotyk i jego aksjologiczna funkcja, którą wykorzystuje pedagog, ma być świadoma i nakierowana na określone wartości, sprzyjające integracji osobowości. Na przykład przekazujące bezinteresowną miłość, szczere zaciekawienie, szacunek czy dodającą odwagi. Świadomość gestu i jego rozwojowo-wychowawczego znaczenia dla dziecka oraz jego wewnętrzna spójność i konsekwencja rozciąga się od aksjologii intencji przez aksjologię jakości komunikatu po sprawdzenie aksjologicznej jakości ich przeżywania i rozumienia przez dziecko w jego świecie wartości ${ }^{24}$. Tym samym zapytany o intencje i uzasadnienia swego działania pedagog może przekazać z poziomu wartości duchowych komunikat też dotyczący tego poziomu: „ochraniam cię, doceniam, co robisz, wspieram twoją energię byś był mocny sam dla siebie, lecz też z całą naturalnością nawiązywał bliskie kontakty, wchodził w relacje i konfrontacje". Jak pisze Lowen, „U osoby zdrowej pulsacja ta jest silna i trwała, co skłania ją do nawiązywania bliskiego kontaktu ze wszystkim i wszystkimi w swoim otoczeniu" (tamże: 41). W regulacji tego pulsowania odgrywa znaczącą rolę duchowość samego pedagoga wyrażona gracją jego ciała oraz samoświadomość ich wzajemnej zależności. Ciało traci grację, kiedy się kurczy, a mięśnie pozostają napięte (lub za bardzo rozluźnione, jak np. po dłuższej chorobie).

Poniżej przedstawię dwa przykłady sytuacji, w których duchowość dziecka może utracić bądź zachować swoją grację, a które związane są z odnoszeniem się do nich bliskich im osób dorosłych.

Płacz. Zdarza się bardzo często. Lowen podaje bardzo „zwykły” przykład dziecka, które jest przemęczone i zarazem nadmiernie podniecone i niespokojne. Nie może zasnąć. Jeśli rodzic, by je uspokoić (sic!), krzyknie na nie, dziecko praw-

\footnotetext{
${ }^{23} \mathrm{~W}$ grę tu będzie wchodzić gadamerowskie przedrozumienie uwikłane w pierwotność hermeneutycznego doświadczenia kulturowego (Gadamer 1993), w którego skład wchodzi też społeczne oczekiwanie na określony sposób przeżywania rzeczywistości. Na przykład brak akceptacji dla płaczu dziecka albo złość wyrażana wulgaryzmami. Funkcję płaczu w radzeniu sobie z trudnymi doświadczeniami duchowymi omawiam nieco niżej.

${ }^{24}$ Chodzi o sprawdzenie podstawowej zasady moralnej, że „do dobrego celu mają prowadzić dobre środki”, a nie przewrotna aksjologicznie zasada niekonsekwencji moralnej, że „cel uświęca środki” (Tischner 1984: 81-84). Spór, jaki może się w tych kwestiach toczyć pomiędzy pedagogami, musi być oparty zarówno na aksjologii postulatywnej, jak i wynikach badań empirycznych dotyczących całożyciowej natury rozwoju człowieka.
} 
dopodobnie rozpłacze się. Jego napięcie emocjonalne samoistnie przekroczy barierę zatrzymywania ich $\mathrm{w}$ ciele. Ten spontaniczny ruch ciała pomoże jednak dziecku rozluźnić powstałe na głębszym poziomie napięcia. Jeśli rodzice je obejmą i przytulą, ich gest przyniesie z jednej strony akceptację bólu dziecka, z drugiej jego fizyczne i uczuciowe (bo płynące $z$ miłości) ciepło ukoi przeżywane emocje i pozwoli odzyskać energię potrzebną do odpoczynku25. Jeśli rodzice tego gestu nie uczynią, lecz jeszcze bardziej zniecierpliwieni, a może i rozgniewani okażą chłód i niezadowolenie wobec dziecięcych emocji i związanych z nim cielesnych napięć (np. wychodząc znacząco z pokoju), to dziecko najprawdopodobniej - wyczerpane płaczem, który nieraz zostaje mu zakazany albo wyśmiany, w końcu zaśnie. Lecz nie odzyska w ten sposób energii, w czym może mu pomóc ciepło ciała rodzica, jego obejmujące ramiona, które oznaczają komunikat: „jesteś bezpieczny, jestem przy tobie". Kiedy dziecko samo utula się w płaczu (a właściwie jego biopsychika) wyczerpuje swoją energię i zasypia nie tyle uspokojone, co wyczerpane (Lowen 2012: 74). Organizm pozostaje w przeżyciu, że kiedy jest mu źle, to musi sobie sam jakoś poradzić, żeby zasnąć, a też, że jakaś namiastka poczucia bezpieczeństwa możliwa jest wtedy, kiedy nie angażuje bliskich do pomocy sobie. Deprecjonuje swoją naturalną słabość i potrzebę wspierającej obecności bliskich mu osób, ponieważ aprobatę/miłość ich (w jego przekonaniu) zyskuje wtedy, kiedy oni nie muszą $\mathrm{w}$ jego przeżyciach współuczestniczyć. Dziecko dorasta też wtedy w deficycie umiejętności sięgania po wsparcie, ponieważ nie nauczono je brać, a tym samym dawać.

Doświadczające szeregu takich sytuacji dziecko może w dorosłości nie umieć zaszlochać z rozpaczy, bólu czy smutku i skorzystać z tej naturalnej reakcji regulacyjnej pulsowanie i przepływ energii $\mathrm{w}$ organizmie. Wstydzi się też płakać $\mathrm{z}$ radości. Spłynie może kilka łez, lecz do dobroczynnego rozluźnienia tonusu ciała i możliwości odzyskania jego gracji nie dojdzie. Lowen uważa, że człowiek „tłumiąc swój płacz, tłumi także swą zdolność kochania" (tamże: 154). Ze swej strony dodałabym, że tłumi i traci zdolność jej naturalnego przeżywania oraz wyrażania poprzez ciało (np. poprzez odczuwane wzruszenie, łagodność, serdeczność, radość, przyjemność czy ciepłe gesty).

Łamanie ducha czy inaczej wolnej woli. Na początek cytat z tekstu Lowena:

Nic nie potrafi tak rozwścieczyć rodzica jak zbuntowane i nieposłuszne dziecko. Rodzice reagują tak, jak gdyby dziecko, poprzez niepoddawanie się ich woli lub sprzeciwianie się ich władzy, zadawało im śmiertelną ranę. Często źródłem takiej furii są rany, jakie zadano rodzicowi, gdy sam był dzieckiem - złamanie jego własnego ducha, gdy został ukarany za to, że śmiał przeciwstawić się autorytarnemu, niekochającemu ojcu lub matce (tamże: 79).

\footnotetext{
${ }^{25}$ Lowen cytuje za: Johnem C. Pierrakos: „Energia z wnętrza ciała wypływa także na zewnątrz, podobnie jak fale ciepła rozchodzą się od rozżarzonego metalowego przedmiotu" (Pierrakos 1970: 60).
} 
Stłumiony wiele lat wcześniej gniew rodzica nie przestaje istnieć. Pozostaje on w jego osobowości na poziomie nieświadomości i czeka, by uwolnić się w sytuacjach, które przypomną go rodzicowi. W dorosłości ujawnia się nieraz z ogromną siłą w sytuacjach, w których np. słabsze fizycznie i psychicznie dziecko miałoby uzyskać od niego to, czego jego samego pozbawiono, bo niby: „Dlaczego ty miałbyś być wolnym duchem, gdy ja zostałem złamany?” (tamże: 80). Głębsza rozmowa i praca terapeutyczna doprowadziłaby prawdopodobnie do uświadomienia sobie przez dorosłego, że jego gniew tylko częściowo jest związany z obecną sytuacją; a że jego pozostała część oraz sposób wyrażania (co z rozwojowego i wychowawczego punktu widzenia ma w relacjach kluczowe znaczenie) wymodelowane zostały przez jego rodziców, kiedy był dzieckiem. Teraz jego dziecko „dostaje” złość, której on sam nie mógł wyrazić do swoich rodziców ${ }^{26}$, oraz być może irytację faktycznie wywołaną aktualną sytuacją.

W rozumieniu Aleksandra Lowena określenie „złamanego ducha” nie jest metaforą, lecz pojęciem faktycznie oddającym „fizyczną rzeczywistość w ciele jednostki". Opisuje to następująco:

(...) każda osoba, której duch został złamany, nosi w sobie stłumioną wściekłość zamkniętą w napięciu mięśni górnej części pleców i barków. Napięcie to możemy dostrzec jako złamanie naturalnej linii pleców, jako przesadną wypukłość tuż poniżej barków albo też w dolnej części pleców jako lordozę lub spłaszczenie wygięcia lędźwiowego. (...) Jednym z urazów powodujących ten stan są mocne lub częste klapsy (tamże: 80).

Podobne zmiany w postawie może też prowokować samo straszenie biciem, które wywołuje odruch obronny „podwiniętego ogona” i (lub) zaciskania pośladków. Człowiek chroni się w ten sposób przed bólem, lecz też upokorzeniem i naruszeniem jego godności (poziom wartości duchowych). Wszak jest to dotknięcie dość intymnego miejsca człowieka, zwłaszcza gdy odbywa się na gołe ciało. To, że zachowanie wolnej woli $\mathrm{w}$ dysponowaniu swoją intymnością jest podstawą ludzkiego poczucia wartości, podmiotowości i godności świadczą konsekwencje erotycznego i seksualnego wykorzystania dzieci i młodzieży.

Zdaniem Lowena w zdrowym rozwoju dziecka chodzi o uchwycenie równowagi między ego a ciałem, między wolą a ochotą. On sam porównuje ten stosunek do jeźdźca (ego) i konia (ochoty). To porównanie wydaje mi się bardzo trafne i obrazujące harmonijne funkcjonowanie człowieka z przyrodą, również w samym sobie. Brzmi następująco: „Jak kłusujący koń, ochota dostarcza siły napędowej do czynu. Tymczasem wola nadaje jej kierunek i kontroluje ją, tak jak uczyniłby to jeździec. Nie jest jednak funkcją woli poskramianie ducha" (tamże: 65).

${ }^{26} \mathrm{~W}$ analizie tego rodzaju zachowań bardzo pomocna jest też Analiza Transakcyjna Erica Berne’a (2010). 
W zasadzie ostatnie zdanie powinno chyba brzmieć: nie jest funkcją woli poskramianie ducha ciała czy też po prostu ochoty. Jej funkcją natomiast jest świadome prowadzenie. „Poskramianie” jest tu rozumiane jako przemoc, przymus i nieoczekujące zrozumienia nakazy i zakazy, które ignorują świat przeżywany i wolę dziecka jako możliwego partnera, ignorując tym samym też jego intelekt. I wola, i umysł znajdują się na poziomie wartości wyższego rzędu. Nie dochodzi jednak do ich wykształcenia, ponieważ wola rodzica, ogarnięta własnymi emocjami, czy pedagoga traci swoją mądrość i świadomość siebie. Wola i ochota dziecka traktowane są jako jedno, a właściwie to jego wola zostaje przez rodzica zredukowana do czystej ochoty. A jak jest po stronie rodzica? U niego ma miejsce niekonsekwencja moralna, ponieważ intencja działania wychowawczego nie współgra z czynem. W intencji i celu zachowania może nawet dominować wyobrażenie „woli prowadzącej ochotę”, lecz w czynie dorosłego mądrość woli i miłość nie są w stanie się przebić przez dotychczas tłumione emocje gniewu czy wręcz wściekłości. Te pozostają u niego na poziomie wartości niższego rzędu i czysto biologicznej przemocy. To w osobowości dorosłego ciało i duch są rozszczepione i nie potrafią się ze sobą „dogadać”. Umysł doskonale wie, co być powinno, lecz emocje i ciało zupełnie nie wiedzą, jak to zrobić. Dorosły odtwarza więc zachowania, które zostały utrwalone w jego osobowości podczas jego własnych dziecięcych i młodzieńczych relacji ze znaczącymi dorosłymi.

Zachowanie łamiące wolę dziecka może mieć swój początek w najlepszych intencjach opiekunów - dorośli chcą, by dzieci (dla swego dobra - sic!) podporządkowały się określonym wymaganiom społecznym, które oni sami postrzegają jako dla nich najlepsze: wysokie oceny w szkole, zdyscyplinowanie, posiadanie prestiżowych umiejętności typu: gra w tenisa, balet czy gra na instrumencie. Początek ich tkwi w wieku ok. 2-3 lat, kiedy dziecko potrafi już wyrazić swoją wolę, co najczęściej wyraża poprzez słówko „nie”. W tym okresie rozwoju jest to jego naturalny sprzeciw będący rezultatem interakcji ciała z bodźcami zewnętrznymi i wewnętrznymi (np. jedzenie, wypróżnianie, ciepło, zimno czy ciekawość). Jeśli napotka ono ze strony dorosłych przymus wiążący się z przemocą, jednoznacznym autorytaryzmem i oczekiwaniem bezwzględnego posłuszeństwa, a dorośli nie uczynią wysiłku, by wejść w relację ze sprzeciwem dziecka poprzez jego zrozumienie (które nie wyklucza możliwości bycia stanowczym), to tak zablokowane ujście emocjonalno-wolicjonalnej energii życia przeradza się w wewnętrzny konflikt, którego przejawami stają się bierność lub bunt. Kierowane pierwszoplanową potrzebą bezpieczeństwa dziecko wykona polecenie (choć czynności fizjologiczne, podobnie jak wyższe uczucia, to największa przestrzeń wolności człowieka) i zrobi to, co nakazane po to, by uzyskać rzecz dla niego w tym momencie najcenniejszą: aprobatę osoby znaczącej, której zachowaniom nadaje znaczenie miłości. Będzie więc jeść, bo mama krzyczy, obraża się albo prosi tak „przesłodzonym” tonem, że „niedobrze się robi”. I dziecko, choć potem nieraz zwymiotuje, będzie się uczyć na szóstki, choć na poziomie nieświadomym będzie przeżywać paniczne lęki przed dezaprobatą 
rodziców oraz ujawnieniem, że podoba mu się co innego, co sprawia mu (jej) satysfakcję i z czym wiąże się przyjemne uczucie samorealizacji (Miller 1995; Maslow 2013: cz. III).

Łamanie woli dziecka może się odbywać przy zastosowaniu twardej, fizycznej lub psychicznej, przemocy typu: krzyk, bicie, emocjonalny chłód, wymuszanie presją psychiczną, lecz też może być ona również „łamana” w sposób „miękki”, kiedy to osoba znacząca uwodzi i szantażuje emocjonalnie dziecko własną słabością (Schier 2014; Sunderland 2019). Na przykład znerwicowana matka swoją lękowością i nadopiekuńczością doprowadza, że dziecko rezygnuje, a nawet nie bierze pod uwagę, że może chcieć czegoś innego aniżeli ona. Zniewolone niezrealizowanymi potrzebami uczuciowymi dorosłego oraz poczuciem winy i braku lojalności w przypadku niechęci do tych „nieswoich” potrzeb karze siebie za własne pragnienia, potrzeby, myśli, emocje i postępowanie. Z perspektywy rozwoju charakteru są to głównie problemy społecznego masochizmu i tworzenia się wzorców samozniszczenia (wiek 0-3 lata) (Johnson 1994: 248-266). Dziecko traci zdolność doświadczania własnych potrzeb i ewentualnego korygowania sposobu ich zaspokajania oraz wspierania siebie (a nie niszczenia) - co jest zadaniem procesu wychowania właśnie w kontekście wartości duchowych. Jego ciało zaś traci swoją naturalną, pełną gracji ekspresję.

\section{Tematy i sprawy ważne dla pedagoga - podsumowanie}

W powyższym tekście opisałam w dość ramowy i wyrywkowy sposób mechanizm współgrania ze sobą cielesności i duchowości w procesie rozwoju i zarazem wychowania człowieka. W tę grę pomiędzy ciałem i duchowością wpisane są, jako ich łącznik, emocje i uczucia. Bliższe funkcjom ciała są emocje, bliższe funkcjom duchowości uczucia, podobnie jak u Schelera bliższe funkcjom ciała są wartości utylitarne, hedonistyczne i witalne, a duchowości - wartości duchowe i święte. Rozdzielać je można wyłącznie intelektualnie i teoretycznie, lecz nie w momencie ich doświadczania, kiedy są ze sobą ściśle powiązane z przeżywanymi emocjami, rozumowaniem i reakcjami ciała. Z pedagogicznej perspektywy warto pamiętać, że sposób ich doświadczania zaczyna się w poczuciu bezpieczeństwa tworzonego w trakcie obcowania cielesnego z mamą bądź w wyniku jego braku. Znowu odwołam się do opisu Lowena:

Doświadczenia pozytywne - czuła opieka, oparcie, tkliwość, aprobata - pozostawiają ciało dziecka miękkim, naturalnym i wdzięcznym. Dziecko doświadcza swego ciała jako źródła radości i przyjemności, więc utożsamia się z nim i odczuwa łączność ze swą zwierzęcą naturą. Takie dziecko wyrośnie na osobę dobrze osadzoną w rzeczywistości, obdarzoną silnym poczuciem wewnętrznego bezpieczeństwa (Lowen 1991: 107). 
Przenośnie można powiedzieć, że człowiek taki jest „zakorzeniony” w tym, co dzieje się tu i teraz i ma odwagę do konfrontowania się ze zmienną i nieoczekiwaną rzeczywistością, na każdym z jej wymiarów wartości. Człowiek zakorzeniony, mocno stojący na nogach może w swym rozwoju duchowym sięgać wysoko i nie odrywać się od realiów (np. poprzez moralizowanie i nieustające powoływanie się na to, co być powinno, bez uważnego respektu wobec tego, co jest i analizy uwarunkowań stanu jaki jest ${ }^{27}$ ).

I jednocześnie, jaki pisze dalej Lowen: „(...) gdy dziecko odczuwa brak miłości i oparcia ze strony matki, jego ciało robi się sztywne”. To reakcja na jej emocjonalny chłód, który pozbawia je:

(...) łączności z jego pierwotną rzeczywistością (...) Każda niepewność jaką dziecko odczuwa w stosunkach z matką, znajdzie odbicie w strukturze jego ciała. Dziecko będzie podświadomie napinało przeponę, wstrzymywało oddech i unosiło barki ze strachu. Jeśli jego niepewność odłoży się w strukturze jego ciała, to wpadnie w błędne koło, gdyż będzie odczuwało brak pewności jeszcze długo po tym, jak przestanie być zależne od matki (tamże: 107).

Ciało dziecka zapisuje więc całą gamę emocji, które towarzyszą słowom, przeżyciom i zachowaniom dorosłych. To zjawisko nazwałabym cielesnością ducha. To, co duchowe, po stronie opiekunów przekazywane jest dzieciom poprzez ich ciało ciału dziecka. I jednocześnie ciało dziecka napełnia się duchową energią (zawartą w sposobie przeżywania siebie - w tym własnych myśli i innych) rodziców, a w miarę jak wzrasta, innych osób dorosłych: wujków, ciotek, dziadków, sąsiadów, nauczycieli, instruktorów. Ciało jest więc, jako takie, nośnikiem ludzkiej duchowości.

Kluczem do zrównoważenia pomiędzy ciałem i umysłem są emocje. Konflikt pomiędzy nimi polegający głównie na konflikcie pomiędzy tym „czego się chce a tym, co się powinno" doprowadza zarówno do utraty spokoju umysłu, jak i gracji w ciele. Osoba pozostająca w konflikcie emocjonalnym często cierpi na nadmiar myśli, które ją pochłaniają i zarazem odsuwają od rzeczywistości. Intelektualne próby przezwyciężenia konfliktu nie przynoszą bardzo często efektu. Lowen zwraca uwagę, że:

Stałe zajmowanie się tym, co dzieje się w umyśle, utrudnia uczuciowy kontakt z innymi ludźmi i ze środowiskiem, osłabia zmysł duchowy i obniża zdolność kochania, gdyż miłość, podobnie jak duchowość, zależy od umiejętności sięgania poza granice siebie (tamże: 159).

\footnotetext{
${ }^{27}$ Metodologicznie postawa taka wiąże się z epoché i deskrypcją fenomenologiczną.
} 
Człowiek zubaża w ten sposób nie tylko zdolność kontaktowania się z innymi, lecz również ogranicza możliwość

(...) utożsamiania się (...) ze swym prawdziwym 'ja', którym jest stan odczuwania swego ciała. (...) Jak to ujmuje podstawowa zasada bioenergetyki, człowiek traci kontakt z każdą częścią ciała, w której istnieje chroniczne napięcie mięśniowe. Im sztywniejsze jest ciało, tym mniej w nim czucia i tym bardziej upodabnia się ono do maszyny. Równocześnie mózg staje się bardziej aktywny i dana osoba zaczyna opierać poczucie siebie wyłącznie na swoich procesach myślowych. Ciało staje się zaledwie aparatem do przenoszenia głowy i do wykonywania jej myśli. W takiej osobie jest bardzo mało życia, a także niewiele duchowości (tamże: 159-160).

Świadomość przebiegu powyżej opisanych procesów, dotyczących współgrania ze sobą ciała i ducha jako bazy zdrowej osobowości, która rozwija się i bogaci w toku wychowania i kształcenia wydaje się być ważna dla przyszłych rodziców, lecz w naszym przypadku wydaje się podstawowa dla nauczycieli, wychowawców czy instruktorów. Przychodzimy do dzieci i młodych ludzi już na określonym etapie ich życia i każde z nich wnosi do relacji z nami własny bagaż doświadczeń i konfliktów emocjonalnych, które ich organizm - po to, by przeżyć - doraźnie rozwiązywał na własne sposoby. Można też zauważyć, że gracja ciała spontanicznie przejawiana jeszcze u dzieci $\mathrm{w}$ wieku przedszkolnym i wczesnoszkolnym, $\mathrm{z}$ biegiem lat ulega usztywnieniu, a dorosły człowiek na pytanie: „co czujesz?” odpowiada najczęściej: „myślę, że czuję”. To znamienne, jak ten powszechny komunikat pokazuje utratę bezpośredniego kontaktu z czuciem własnych emocji, właśnie dzięki swojemu ciału. Emocje i uczucia przestają być harmonijnym łącznikiem, ponieważ poruszają się po ambiwalentnych skrajnościach. Albo są wyrażane bezmyślnym zachowaniem (np. odreagowywanie wściekłości poprzez niszczenie obojętnie czego, też samego siebie), albo chowane za myśleniem (intelektualizowanie) i zajmowanie się bardziej wyobrażeniami aniżeli faktami.

Co możemy jako dorośli i w dodatku profesjonalnie przygotowywani pedagodzy zrobić dla dzieci i młodzieży?

Po pierwsze: uzyskać na ten temat wiedzę. Po drugie: przejąć się nią i tym, że jesteśmy częścią ich dzieciństwa i młodości i że w relacji z nami mogą oni tracić lub w dostępnym nam zakresie odzyskiwać swoją grację ciała i spokój ducha. Po trzecie: odbyć osobistą podróż w celu odkrycia tego, co w naszym indywidualnym procesie „wychowywania nas” zakłóciło zdrową relację pomiędzy doczesnymi emocjami, doznaniami ciała i myślami, a co dla wielu osób ujawnia się dodatkowo na tle fenomenologicznie i obiektywnie doświadczanego porządku wartości. Po czwarte: jako człowiek dorosły - w miarę obecnych możliwości i wewnętrznej uczciwości nie tylko poznać, lecz i zmienić, by budować metodykę relacji w oparciu o przepracowaną, wewnątrzsterowną i świadomą holistycznie rozumianą duchowość. 
Niewątpliwie najwięcej kłopotu w podjęciu takiej wewnętrznej zmiany sprawia ujawnianie głębokich emocji i uczuć. Dzieje tak, ponieważ towarzyszy człowiekowi obawa, że gdy raz się one odezwą, to utraci nad nimi kontrolę i nie będzie mógł sobie z nimi poradzić. Dlatego wybiera nieraz ich ukrywanie, żyjąc pozorem „panowania nad nimi”. Wspomniana obawa przed niekontrolowaną i jednocześnie nieakceptowaną ekspresją emocji ma swoje źródło w doświadczeniach dziecięcych, które zdominowane były właśnie lękiem. Jest to oczywiste. Bałam się jako dziecko, boję się i teraz na samo wspomnienie. Lecz, jak argumentuje Lowen: „Obecnie jako ludzie dorośli nie jesteśmy już bezradni, ani zależni, lecz dojrzalsi, jeśli chodzi o rozumienie życia" (tamże: 85). Możemy nie tylko zaopiekować się swoim wewnętrznym dzieckiem (Karpowicz 2007), lecz też sięgać w swym profesjonalnym rozwoju po pomoc psychoterapeutyczną ${ }^{28}$. 0 ile jednak, w procesie psychoterapii osoba dorosła ${ }^{29}$ czyni wysiłek zrozumienia (i emocjonalnego przepracowania) okoliczności, które konstytuowały jej osobowość oraz wprowadzenia realnych zmian w sposobie swojego dotychczasowego funkcjonowania, o tyle w sytuacjach wychowawczych, oprócz wiedzy o samym sobie, istotne będzie ze strony pedagoga rozumienie tego, w jaki sposób zauważalne dziś zakłócenia w funkcjonowaniu dziecka były tworzone i jakie potrzeby rozwojowe dziecka zostały w jego środowisku wychowawczym (rodzinnym, rówieśniczym szkolnym i pozaszkolnym) zdeprywowane. Zaś jego celem pragmatycznym będzie optymalizacja aktualnych warunków w taki sposób, by potrzeby rozwojowe wychowanka mogły być realizowane w kierunku integracji jego osobowości. W moim głębokim przekonaniu są nimi relacje, budowane przez pedagoga w oparciu o świadomość cielesności ludzkiego ducha i duchowości jego ciała.

\section{Bibliografia}

Ablewicz K. (2003a) Badania hermeneutyczne w pedagogice w: Encyklopedia pedagogiczna XXI wieku, T. I, Warszawa, Wydawnictwo Akademickie „Żak”.

Ablewicz K. (2003b) Teoretyczne i metodologiczne podstawy pedagogiki antropologicznej. Studium sytuacji wychowawczej, Kraków, Wydawnictwo Uniwersytetu Jagiellońskiego.

\footnotetext{
${ }^{28}$ Jestem też przekonania o potrzebie wprowadzania dla pedagogów nie tylko superwizji metodycznych, lecz też rozwojowych pozwalających świadomie sprawdzić osobowościowe schematy i kulturowe stereotypy. „Niektórzy z nas potrzebują jednak oparcia u terapeuty, by ujawnić swe najgłębsze uczucia" (Lowen 1991: 85).

${ }^{29}$ Psychoterapia generalnie dotyczy człowieka dorosłego, a nie dzieci, wychodzi się bowiem z założenia, że ich kłopoty generowane są głównie poprzez relacje rodzicielskie i to rodzice powinni najpierw sprawdzić własną dojrzałość emocjonalną oraz nabyte nawyki wychowawcze. Najbardziej pożądana w takich sytuacjach jest terapia rodzinna.
} 
Berne E. (2010) W co grają ludzie. Psychologia stosunków międzyludzkich, tłum. P. Izdebski, Warszawa, Wydawnictwo Naukowe PWN.

Bowlby J. (2007) Przywiq̨zanie, tłum. M. Polaszewska-Nicke, Warszawa, Wydawnictwo Naukowe PWN.

Gadamer H. G. (1993) Prawda i metoda. Zarys hermeneutyki filozoficznej, tłum. B. Baran, Kraków, Wydawnictwo inter esse.

Grzegołowska-Klarkowska H. J. (red.) (2015) Psychoanalityczne teorie rozwoju, Warszawa, Wydawnictwo Akademii Pedagogiki Specjalnej.

Hildebrand v. D. (1984) Fundamentalne postawy moralne w: Wobec wartości, D. v. Hildebrand, J. A. Kłoczowski, J. Paściak, J. Tischner (red.), Poznań, „W drodze”, Wydawnictwo Polskiej Prowincji Dominikanów.

Johnson S. M. (1994) Style charakteru, tłum. B. Mizia, Poznań, Zysk i S-ka Wydawnictwo s.j.

Kaplan L. J. (2014) Jedność i oddzielenie. Od niemowlęcia do odrębnej jednostki, tłum. M. Cierpisz, Koszalin, Centrum Pracy z Ciałem Joanna Olchowik.

Karpowicz P. (2007) Terapia swego wewnętrznego dziecka, Warszawa, Eneteia.

Lowen A. (1991) Duchowość ciała, tłum. S. Sikora, Warszawa, Agencja Wydawnicza Jacek Santorski \&CO.

Lowen A. (2012) Depresja i ciało. Biologiczne podstawy wiary i poczucia rzeczywistości, tłum. P. Luboński, Warszawa, Wydawnictwo Czarna Owca.

Lowen A. (2012) Język ciała. Jak ciało pokazuje osobowość. Fizyczna dynamika struktury ciała, tłum.: zespół, Koszalin, Ośrodek bioenergetycznej pracy z ciałem, pomocy i edukacji psychologicznej. Joanna Olchowik.

Maslow A. (2013) Motywacja i osobowość, tłum. J. Radzicki, Warszawa, Wydawnictwo Naukowe PWN.

Miller A. (1995) Dramat udanego dziecka. W poszukiwaniu siebie, tłum. N. Szymańska, Poznań, Media i Rodzina.

Neill A. S. (1994) Nowa Summerhill, tłum. M. Duch, Poznań, Wydawnictwo Zysk i S-ka.

Pierrakos J. C. (1970) The Energy Field of Man, „Energy and Character. The Journal of Bioenergetic Resaerch", vol. 2, Abbotsbury, England.

Rolewski J. (1999) Rozum, nauka, świat przeżywany. Studium filozofii późnego Husserla, Toruń, Wydawnictwo Uniwersytetu Mikołaja Kopernika. 
Santorski J. (oprac.) (1992) Organizm i orgazm. Podręcznik ćwiczeń. Bioenergetyka Lowena. Integrująca psychoterapia ciała Rosenberga. Medytacja i bieg transowy, Warszawa, Santorski \& CO Agencja Wydawnicza.

Scheler M. (1975) Wybór pism w: Scheler, tłum. A. Węgrzecki, Warszawa, Wiedza Powszechna.

Scheler M. (1997) Resentyment a moralność, tłum. J. Garewicz, Warszawa, Czytelnik.

Schier K. (2014) Dorosłe dzieci. Psychologiczna problematyka odwrócenia ról w rodzinie, Warszawa, Wydawnictwo Naukowe Scholar.

Sills Ch., Fish S., Lapworth P. (1999) Pomoc psychologiczna w ujęciu Gestalt, tłum. E. Bielawska-Batorowicz, Warszawa, Instytut Psychologii Zdrowia Polskiego Towarzystwa Psychologicznego.

Stróżewski W. (1992) W kręgu wartości, Kraków, Wydawnictwo Znak.

Sunderland M. (2019) Odwrócona relacja, tłum. A. Sawicka-Chrapkowicz, Sopot, Gdańskie Wydawnictwo Psychologiczne.

Tischner J. (1984) Etyka wartości i nadziei w: D. v. Hildebrandt, J. A. Kłoczowski, J. Paściak, J. Tischner, Wobec wartości, Poznań, „W drodze”, Wydawnictwo Polskiej Prowincji Dominikanów, s. 51-149.

Węgrzecki A. (1975), Scheler, Warszawa, Wiedza Powszechna.

Zinker J. (1991) Proces twórczy w terapii Gestalt. Materiały Laboratorium Psychoedukacji, opracowano na podstawie przekładu roboczego, Warszawa, Santorski \& CO Agencja Wydawnicza.

Żłobicki W. (2009) Edukacja holistyczna w podejściu Gestalt. O wspieraniu rozwoju człowieka, Kraków, Oficyna Wydawnicza „Impuls”.

Żurakowski B. (1998) Edukacja do wyboru wartości w: Tradycja i wyzwania. Edukacja. Niepodległość. Rozwój, (red. nauk.) K. Pacławska, Kraków, Universitas.

\section{Źródła internetowe}

https://peoplepill.com/people/wilhelm-reich/ [dostęp: 09.2020]. 